\title{
Overcoming ‘Gnosticism’? Realism as Political Theology ${ }^{1}$
}

\author{
(Forthcoming in the Cambridge Review of International Affairs)
}

\section{Please do not cite without permission}

\author{
Vassilios Paipais \\ vp31@st-andrews.ac.uk
}

\begin{abstract}
This paper takes issue with approaches that relate realist political theology exclusively back to its Schmittian and neo-orthodox roots. While not entirely denying those influences, it argues that realist thought is more accurately described as rooted in the tensions characterising Augustine's anti-heretic diatribes rather than taking inspiration from Schmittian political theology or the 'Gnostic' tendencies in Protestant neo-orthodox theology. Augustine's refutation of both the Manichean Gnostic and the Pelagian solutions to the problem of evil gave rise to a complex understanding of the relationship between human free will and original sin based on a combination of ontological monism and ethical dualism. Building on this heritage, realists can be read as rehearsing Augustine's ambiguous gesture of overcoming Gnosticism with equally uncertain success. In responding to the modern 'Gnostic' challenge in terms that recognised the dialectical tension between ontological monism and ethical dualism, realists such as Morgenthau and Niebuhr should rather be seen as direct heirs of Augustine's ambivalent orthodoxy rather than Schmitt's unorthodox, semi- 'Gnostic' Catholicism. This intellectual legacy may, then, explain their abhorrence to purist positions in politics -be it quietism, pacifism or, their opposite, political messianism- and adherence to an anti- 'Gnostic' pragmatism grounded on the tensions of Augustinian theology.
\end{abstract}

Keywords: political theology, realism, Augustine, Gnosticism, Morgenthau, Niebuhr

\section{Introduction}

In a recent article on how International Relations (IR) theory emerged in the early ' 50 s as a critique of secularism in the social sciences, Nicolas Guilhot (2010) makes a powerful argument in favour of realigning mid-twentieth century political realism with its theological roots. Guilhot puts forward a well-argued case of realism representing the theological moment in the history of International Relations albeit one that was quite short-lived and destined to succumb to the forces of secularisation in the guise of behavioralism. However, when it comes to outlining the lineages underpinning realist political theology, Guilhot identifies three: the rise of Protestant neo-orthodoxy as a reaction to liberal Christianity, the wave of midcentury Augustinianism and, last but not least, the inspiration offered by Carl

\footnotetext{
${ }^{1}$ I am thankful to Nick Rengger, Tony Lang and three anonymous reviewers of this journal for their insightful comments and to Michael C. Williams for his advice to build the argument of this paper on a rebuttal of Guilhot's article. The remaining mistakes are mine.
} 
Schmitt's critique of liberal modernity. Indeed, it is the latter influence he deems more important as it reveals what he calls the 'Teutonic forest' behind the tree of Protestant neo-orthodoxy and political Augustinianism: 'Schmitt's political theology... represented a strand of Catholic conservatism that resonated with the ideological program of Protestant neo-orthodoxy' (Guilhot 2010, 226).

It is this latter sweeping and rather misleading claim that this paper wants to take issue with. Although the argument for excavating twentieth century political realism's theological pedigree is both plausible and compelling, ${ }^{2}$ Guilhot seems to establish too strong a connection between Schmittian political theology, neoorthodox theology and political realism. Undeniably, as Roger Epp (1991; 2003) has amply shown, realist thought was fundamentally inspired by Augustine's pronouncements on human nature, morality and politics; yet, the connection between realist political theology and Protestant neo-orthodoxy or Schmitt's idiosyncratic Catholicism is not as straightforward as Guilhot would like us to believe. To be sure, there are some common themes and concerns that seem to unite all three projects, such as the attack on liberal modernity, the re-appreciation of the role of religion in politics and the critique of anti-metaphysical positivism. However, realist thought, I argue, is rather firmly rooted in the ambiguities and tensions permeating Augustine's theology than taking inspiration from Schmittian political theology or purist tendencies in Protestant neo-orthodox theology. In contrast to the reliance of Schmitt's political theology (and to certain extent of Protestant neoorthodox theology) on 'Gnostic' themes, realist thought should be seen as a critique of 'Gnosticism' along the lines of Augustine's opposition to ontologically dualist modes of thought. ${ }^{3}$

In fact, this paper suggests that it is exactly the creative ambivalence between Augustinian ontological monism and ethical dualism ${ }^{4}$ that characterises the work of

\footnotetext{
2 Albeit not new, see Hermens (1958); for a focus on the Augustinian tradition in international relations, see Epp (1991; 2003). Particularly on Butterfield and Wight, see Thomas (2001), Hall (2006) and Pabst (2012). See also Jones (2003), for a critique of secularisation in the English School, Rossbach (1999) for an emphasis on George Kennan and Troy (2013) for a political theological treatment of the realist tradition.

${ }^{3}$ The use of inverted commas recognises the polysemy of a disputed term like 'Gnosticism' and the wars of interpretation surrounding its reconstructed use in modern times. The term 'Gnosticism' emerged in $18^{\text {th }}$ century France and is usually employed to denote the Gnostic systems of the second and third centuries AD, particularly those of Basilides, Valentinus and Mani. The term gnostikos was conferred on those movements largely through Christian heresiomachs such as Irenaeus, Tertullian, Hippolytus and Epiphanius. Gnostic studies have enjoyed a renaissance since the discovery of ancient Gnostic texts at Nag Hammadi in 1945 but recent research on the history of late antiquity have taken issue with the term's coherence. The term 'Gnosis' is known in Ancient Greek and Latin texts as opposed to the use of the term 'Gnosticism' which seems to be rather related with twentieth century religious and philosophical polemics than with its late antiquity referent. This latter use has prompted some to talk about Gnosticism as a 'sick sign' that includes everyone and no one under a single semantic umbrella (Lazier 2008, 32). In this article, I am closer to Jonas' understanding of the term as conveying an attitude or stance (Daseinshaltung) toward human being and Gershom Scholem's designation of 'Gnosis' as a reproducible structure in religious thought. Instead of a huge bibliography on the topic, see relevant discussions in Jonas (1992); Lazier (2008); Rossbach (1999); Williams (1996); King (2003). In this paper, the use of the term in inverted commas designates its contested use in modern times whereas, when used without, it is either taken to denote the ancient Gnostic movements or it is part of another thinker's argument.

4. The terms 'ontological monism' and 'ethical dualism' should not be interpreted literally as referring to ontological realities but rather as indices of experiences conveyed through the use of religious language (see Voegelin 1990; Ricoeur 1967). Ontological monism reflects the biblical belief that the world was created 'very good' (kala lian) (Genesis, 1:31) and that created nature includes both the
} 
two of the most prominent realist thinkers, Hans Morgenthau and Reinhold Niebuhr. As I will show, Augustine's refutation of both the Manichean Gnostic and the Pelagian solutions to the problem of evil gave rise to a complex understanding of the relationship between human free will and original sin based on a combination of ontological monism and ethical dualism. Building on this heritage, the realists can be read as rehearsing Augustine's ambiguous gesture of overcoming Gnosticism with equally uncertain success. Indeed, I will argue that Morgenthau and Niebuhr exemplify in varying degrees this ambivalence in resisting the 'Gnostic' temptation, an enterprise that, truth be told, proved challenging even for Augustine himself. In responding, however, to the 'Gnostic' challenge in terms that recognised the dialectical tension between ontological monism and ethical dualism, realists should rather be seen as direct heirs of Augustine's ambivalent orthodoxy rather than Schmitt's peculiar, semi-'Gnostic' Catholicism. This intellectual legacy may, then, explain their abhorrence to purist positions in politics -be it quietism, pacifism or, their opposite, political messianism- and adherence to an anti-'Gnostic' pragmatism grounded on the tensions of Augustinian theology.

\section{Political theology and the 'Gnostic' temptation}

The main argument of this section is that in order to understand realism as an anti'Gnostic' political theology in all its tensions and permutations, one has to revisit the Germanic political theological discussions of the early and mid-twentieth century in which the question of whether modernity constitutes a break from theological habits of thought or not coincided with an acute post-war moral crisis. In the aftermath first of the First World War carnage and later of the Second World War genocidal horror, German-speaking intellectual circles were overwhelmed by a feeling of disenchantment with the liberal-secular character of modern German culture. Though this notion of a crisis of culture related to countless aspects of social life, German-speaking intellectuals endeavoured to identify the roots of the crisis and reach a comprehensive solution. Within the contours of this debate, theological ideas and controversies of the early Christian era were reconstructed to account for what went wrong with modernity. If the secularising process ended up in a land of screams', perhaps the wisdom contained in long-abandoned theological discourses could provide a clue as to why the idea of progress, among other liberal illusions, proved to be such a chimera.

The debate was ignited by a thesis put forward in 1949 by the German-Jewish scholar Karl Löwith, a former student of Martin Heidegger. In his book published that year, entitled Meaning in History, Löwith (1949) defined modernity as secularised Christian theology. Löwith's main thesis in that book was that the modern belief in progress is a direct extension of late medieval eschatology and, more concretely, a continuation of the eschatological philosophy of history of Joachim of Flora (Löwith 1949, 145-159). In challenging Augustine's categorical disjunction between the historical world of mankind and the transcendent sphere of God, Joachim of Flora was, according to Löwith, the first to ascribe a redemptive end to the historical process as such. Löwith's provocative thesis was essentially an endorsement of Carl Schmitt's (2006, 36) earlier aphorism that 'all significant

material and the spiritual world ascribing ontological primacy to neither. Ethical dualism then is the doctrine that reads the introduction of evil and suffering in the world as a product of the human will which had as a result the denigration, yet not the destruction, of the ability of human nature to liken God. 
concepts of the modern theory of the state are secularised theological concepts'. While Schmitt's dictum, however, was attached to a critique of the juridification of what were essentially political matters, Löwith's argument was pointing to human inability to overcome theology, not only because modern times emerged out of the medieval era but, more profoundly, because secularisation was nothing more than a 'transfiguration' of Christian theology (Taubes 2004, 55) in modern semantics.

What Löwith read as the mark of Christian eschatology in the heart of modernity, however, Eric Voegelin (1952: 107-32) was inclined to interpret as the expression of a Gnostic revival attempting 'to give a "meaning" to the immanent course of history' (cf. Hotam, 2007: 598). Reading the works of Joachim of Flora as Gnostic rather than Christian in character, Voegelin argued that the modern concept of progress is Gnostic to the extent that secularisation inflates the Gnostic concept of a true and hidden divine light within the human being and transposes it into the new worldly reality. Voegelin holds that this process of 'immanentisation of transcendence' -as he labelled the attribution of the qualities and features of the divine and sacred to the worldly and mundane- eventually leads to the re-divinisation of man itself and his worldly existence. By calling modernity a secularised Gnostic heresy, Voegelin condemned not only the modern liberal order but all forms of utopian or totalitarian politics as well, such as socialism, communism and fascism for projecting intramundane salvific doctrines as ultimate truths. The predictable result is modern nihilism: the death of God and its replacement by man as the modern Prometheus ${ }^{5}$ who brought the catastrophes of the twentieth century upon himself.

Voegelin identified Prometheanism as the major fault of 'Gnostic' theology and, yet, the Luciferian sin defines only one aspect of 'Gnostic' dualism. The belief in human beings' infinite potential is coupled with a correspondent utter disregard of the natural and historical world, in turn closely related to 'Gnostic' theodicy. ${ }^{6}$ The primary aspect of 'Gnostic' thought is a sharp dichotomy between a good transcendent God and an evil world which is the creation of a lesser malicious deity. As a result, 'Gnosticism' introduces a dualism of transcendence (God) and immanence (existence within this world), an irreconcilable division between the 'eternal' and the 'temporal'. Furthermore, given the dichotomy 'true God vs. evil world' (or between 'eternity' and 'temporality'), true 'Gnosis' presupposes the alienation of the transcendent God from the world as we know it (Jonas 1992). The true transcendent God is a hidden and concealed divinity (Deus absconditus) who cannot be held responsible for the evil in the world as He is not the creator of the world; the world is believed to be the creation of a lesser and evil Godly power (demiurge), always at loggerheads with the one true transcendent Divine entity. Finally, 'Gnostic' anthropology transposes cosmic dualism onto the human being's constitution itself. Human beings are torn between worldly existence and a divine and hidden inner essence, stranded between immanence and transcendence, the 'eternal' and the 'temporal'. Humanity's mission according to 'Gnosis' is to reignite

\footnotetext{
${ }^{5}$ Contra Voegelin, Hans Blumenberg, in his major work The Legitimacy of the Modern Age, challenged the designation of modernity as Gnostic. He found the Gnostic spirit revived in the nominalism and theological voluntarism of late medieval scholastic theology revolving around the abyssal omnipotence of a Deus Absconditus or hidden god. Whereas the first partially successful attempt at Gnosticism's overcoming was Augustine's work, the second, and for Blumenberg 'final' overcoming, was premised on the ontological revaluation of nature through an ethos of human 'self-assertion' best instantiated in the scientific program of Francis Bacon (see Blumenberg, 1985, 127-143).

${ }^{6}$ For a dissenting view that describes the criticisms of 'Gnostic' dualism as 'Christian heresiophobia', see the work of Arthur Versluis (2010; 2006)
} 
the divine spark already dormant in human spirit by disassociating itself from worldly existence. The rejection of the world and temporality is absolute here. Disbelief in the world and estrangement from it are the symbol of the 'Gnostic' existential state of mind in its quest for self-revelation and redemption (Jonas 1992: 320-40; see also Rossbach 1999).

If 'Gnostic' theodicy is the key to understanding its otherworldliness, Voegelin is, then, probably wrong in attributing to 'Gnosticism' a tendency to 'immanentise the eschaton'. ${ }^{7}$ According to this reading, 'Gnosticism' appears to abhor any effort to establish an earthly paradise as much as Christian eschatological reservations reject the possibility of any worldly power being identified with the Kingdom of God. The difference, of course, lies in the 'Gnostic' response to the problem of evil. As opposed to Christian monism that considers nature created good and thus ontologically predisposed to salvation, 'Gnostic' dualism locates the existence of evil in the world, or to be more precise, perceives the world as the evil that must be overcome (Jonas 1992, 329). This part of 'Gnostic' legacy proved so powerful as to have exerted a compelling attraction not only to philosophical circles that were interested in the use of theological terms to describe the modern experience, but also among theological circles that struggled to formulate a Christian response to the appropriate relationship between faith and political engagement after the devastating experience of the First World War. The major figure of the neo-orthodox movement, Karl Barth (1968), flirted with aspects of the 'Gnostic' worldview, despite later repudiating them (Barth 1960, 46, 62). Barth's Platonic assertion that God was absolutely separate from humanity sought to restore the certainty of meaning by removing its source from the changing and transitory world of humanity. Barth had reasons to mistrust the close association of the divine and the temporal realms. The theology of crisis, of which his was a prominent representative, sprung out of the critique of liberal Protestantism for establishing too intimate a connection between throne and altar. Barth's idea of krisis was exactly the rejection of any humancentred solutions to the ambiguities of history in the form of messianic ideologies pointing towards a heaven on earth and seeking to bring divine perfection into a fallible earth or bridge the gap between divine eternity and human time (Cremer 1995: 294). While fighting the temptation to 'immanentise the eschaton' on the one hand, Barth's almost absolute dichotomy between the divine (God as Deus absconditus) and the profane (temporality, human history) reintroduced the 'Gnostic' politics of purism, on the other (Lilla, 2007: 262).

Yet, Barth's refusal to sanction the social world begs the question of what makes a reformist theological movement such as neo-orthodoxy susceptible to the 'Gnostic' temptation. One has to revisit here the Pauline roots of the neo-orthodox revival. Indeed, Saint Paul, as it was said for his master Jesus Christ, has been a point of contention. The evocation of his legacy in religious thought and dogmatic history usually means trouble for institutional Christianity as his thought combines both the announcement of a new order and the self-revolutionising of that order (Critchley 2012, 155). In Christian parlance, Paul attempts to work within the law, yet understood in its messianic transformation as something that conditions our relation with faith and redemption. Throughout history the Pauline message has been

\footnotetext{
7 In fact, this is an observation one of the most astute and sympathetic readers of Voegelin, Gregor Sebba, arrived at. Investigating the issue of the empirical validity of the continuity between ancient and modern forms of 'Gnostic' thought, Sebba concluded that what characterises 'classical gnosis' is exactly the 'radical rejection of any immanentisation of transcendence' (cf. Rossbach 2005, 106).
} 
interpreted in various ways, either as legitimist to the 'powers that be' or as entirely antinomic, opposed to the order of being that represents man's sinfulness and constitutive imperfection. The latter impulse has been the inspiration behind reactions against the secularism, corruption and scholasticism of the established Church towards the uncovering of the authentic core of Christianity. What usually happened when Paul was evoked was that the official church was recognised as the Whore of Babylon in need of reformation and realignment with the roots of true unalloyed faith. If the signifier 'Paul' denotes anything, that is the need for reformist action, the demand for activism and vigilance against complacent pietism or worldly powers and institutions that think of themselves well-grounded and secure in their legitimacy.

In this context, Paul has been the inspiration for both heretics and reformers within the established Church. This is true of Marcion's Gnostic critique of the Apostolic Fathers, Augustine's response to Gnosticism and Pelagianism, and Luther after the Scholastics up to the neo-orthodox movement as a reaction to liberal Protestantism. The Pauline moment represents the spirit of reform and uncompromising return to the authentic core of faith. My purpose here is not to pit those that defend Paul's orthodoxy against those who read him as a Christian Gnostic. But to point to how Paul's uncompromising spirit and radical messianism can be seen as both reflecting and enacting the temptation of ontological dualism in religious thought. For Jonas, who detected a clear Gnostic vein in Paul, the problem with Pauline antinomianism was what he termed a tendency towards 'de-worldification' (Entweltlichung), a stance he collectively attributed to all modern day 'Gnostics', from Barth and neoorthodoxy up to Heidegger's existentialism (Lazier 2008, 27-48). More specifically, a tendency in 'Gnosticism' to equate the Pauline 'flesh', that stood for anything worldly, with sin and, thereby, deprive humans of their prelapsarian or primordial grace. For Jonas, both Paul and later Augustine -who, in Jonas' view, in his attack against the Pelagians failed to escape the Gnostic bind-, opted for the equation of human finitude ('law') with sin. As a result, any prospect of humans participating in their salvation through lawful piety ('works') was apriori excluded and what began as an ethical opposition between 'flesh' and 'spirit' was now turned into an unbridgeable rift between the world and divine grace. The point of this discussion is not to endorse Jonas' take on Paul, Augustine or Barth. It is only partly that Paul's own ambivalence can be held responsible here as it is also partly an inherent tendency in religious thought to slide towards dualistic categories of justification instead of maintaining the dialectical tension between the law, the order of being, immanence on the one side and love, the order of faith, transcendence on the other (Lilla 2007, 251-2). And Jonas does point here, albeit unintentionally (Lazier 2008, 34), to a constant 'Gnostic' temptation in religious thought as the inability to sustain the dialectical paradox of religious experience and the tendency to fall back to ontological dualism in search for purity and security; what the theologian Johann Baptist Metz would describe as the "gnostische Dauerversuchung" (permanent Gnostic temptation) of the Church (Metz, 1988).

As a reaction to religious conformism and ambiguity, this 'Gnostic' purism arises in two forms that converge in their dualistic orientation; either in the form of the naturalisation of original sin that attributes to human beings an ontological defectiveness or inherent predilection to wickedness, malice, violence and extreme cruelty. Or, its mirror image, in the form of utter disengagement from worldly affairs driven by a purist sentiment of disgust for the imperfection of civilisation. The former is a type of pessimism that is grounded on a nihilistic -and 
fundamentally unchristian- rejection of human beings' capacity for improvement through worldly engagement. The latter is a type of moralism that is grounded on the typically 'Gnostic' idea of an alienated world incapable of redemption. Both result in an essentially dualist anti-political purism that divest human being of any responsibility for changing the world or participating in its betterment. This idea, which relates back to a $2^{\text {nd }}$ century AD Gnostic sect, Marcionism, is tempting yet potentially debilitating. It is tempting because it places responsibility for a defective world to a malevolent deity that has instilled corruption to the world, while exonerating human beings from the blame. It is also alluring because it rests on the idea of religion as pure faith that can detach itself from anything debased or degenerate in the real world and pursue individual perfection through a radical act of renewal and rebirth. Yet, it can be fatalistic as it ultimately relies not on a biblical expectation for the eschatological fulfilment of history but on a conception of theology as retreat from creation and a relation with a God that usurps individual responsibility for the evil in the world (see Critchley 2012, 202). Before moving to examine how the realism of Morgenthau and Niebuhr deals with the allures and perils of 'Gnostic' anti-cosmism, an investigation of Augustine's struggle against the 'Gnostic' temptation may further elucidate the theological legacy upon which realist political theology rests.

\section{Overcoming Gnosticism 1.0? Augustine’s incomplete dialectics}

The implications of the radical break between transcendence and immanence that 'Gnostic' dualism announces has been the focus of Augustine's struggle in his arduous efforts to differentiate orthodox theology from the heretical discourses of both Manichean Gnosticism and Pelagianism. Augustine laboured for nine years under the Gnostic doxas as the piety and asceticism of the Manicheans -the prevailing type of Gnosticism in his time- held a strong appeal for a spiritually tormented young man. The attraction of the Manichean doctrine rested in absolving both man and God from the responsibility for evil. Manichean Gnosticism hinges upon a feeling of incommensurability between the self and its world and expresses this in antagonistic dualisms. Evil is being embodied in an alien, hostile world. This dualism of self and world leads to the dualisms of soul and body, God and cosmos. The soul, exiled from the divine realm by reason of a pre-cosmic fall or error, is incarcerated in the body. Evil and finitude are one and the same. And yet, though sharing in evil, humans are not responsible for it, for ultimately evil is a second ontological principle over against the transcendent alien God. Thus, evil for Gnosticism is almost physical, a contagion infecting the person from without. This elaborate rationalised myth revealed inner man, the spirit, to be untarnished and a part of the divine substance eternally in battle with the external physical world which is the embodiment of evil. Man and God are not guilty for what is bad in the world but are both part of a cosmic redemptive scheme.

Augustine fiercely attacked this doctrine that divided the human being between his soul and his body instilling an irreconcilable animosity between the two elements of its nature. If saving the innocence of the deity demanded rapturing the unity of cosmos and the human self, then the cost, for Augustine, was too high as it left humans alienated from the world and prevented them from experiencing the wholeness of their being: 'but the whole was myself and what divided me against myself was my impiety' (Augustine, 1998: 84). Augustine's theory of sin was an attempt to defend this wholeness (Forsyth, 1987: 396). Human beings are created good and situated in a good creation as opposed to the Manichean and generally 
Gnostic notion that matter itself is evil (DCD 11.22). ${ }^{8}$ Since being and good are primordial, evil can have no ontological status; it is not a being but the privation of being (privatio bonı) (DCD 14.13). Hence, lacking an ontological foundation, it cannot be explained but only described as a free defection of the defectible human being from the order intended by the Creator (Duffy 1988, 599). Evil is turning away from God, the noblest good, and inordinately turning to the world and its volatile, finite goods. It is a self-defeating denial of any authority but the absolutised self. Desire, a natural tendency, becomes, after the Fall, enslaving concupiscence -a technical term used by Augustine to describe the inordinate desire. Sin is a selfimposed shackling that follows upon our misplaced love for the finite instead of the infinite (DCD 14.4).

In defending such anthropology, Augustine strove to eschew both the pessimism of Manichean Gnosticism and the optimism of Pelagianism. Against the Manicheans he maintained that evil is not identifiable with human finitude. It erupts freely, contingently, and not by ontological necessity. Theologically, he came to see that Gnostic dualism is unchristian. The root of evil is the dark misuse of the created gift of freedom, the unravelling of what God had made rather than a tainted nature which is the consequence of sin. The original sin marks a clear separation between the theological genesis of being and the anthropological genesis of evil. With the state of original righteousness forfeited by a historical first sin, Augustine negated the Gnostic coincidence of evil with finitude the same time he rescued the Greek and Biblical sense of the created beauty of the universe and the goodness of the material of which it is made. The human is the point where evil emerges in the world. Augustine's is an ethical vision of evil; humans are integrally responsible. His is not the tragic vision where humans are not actors but victims of a wicked God (see Ricoeur 1974).

Against the Pelagians, on the other hand, Augustine maintained that $\sin$ is not merely accidental or purely contingent. Pelagian voluntarism went further maintaining that freedom is indeterminacy. We basically enter the world from the womb neutral, argued Pelagius, without virtue, but also without vice and can opt for either as we freely weave our life story (Duffy 1988, 601). If sin is voluntary by definition, then humans must be capable of not sinning. Though sin is widespread, it is not a universal condition of humankind. Moral perfection must be a human possibility otherwise that would violate the condition of our God-given freedom and a just God cannot demand the unreasonable. Adam corrupted only himself, not his posterity. He set a bad example which is widely followed; hence an evil influence is socially transmitted as habit or custom. Nonetheless, sin is neither inevitable nor universal. Finally, evil acts do not alter or destroy the ontological condition of human freedom; its indeterminacy or neutrality in the face of good and evil is intact. Impotency before the power of sin is a cowardly rationalisation. Augustine could not live with the simplistic Pelagian reduction of $\sin$ to a conscious, free choice of evil. Universal in its range, though not synonymous with or a structure of essential humanity, it nevertheless appears as a kind of 'second nature', a positive propensity to evil. Corruption of human nature by sin entails a predisposition to evil, a bias toward it, which precedes and forms choice. In virtue of the Fall, this dispositional bias is universal obliging the human will to a kind of pre-volitional bondage.

\footnotetext{
${ }^{8}$ References to Augustine's City of God (De Civitate Dei) are from Dods' (1950) translation.
} 
Unlike Pelagius, Augustine saw that freedom has an acquired nature, for it is encumbered by habit and history. In this he echoed Paul and anticipated Luther. Obviously, such a position gives rise to problems. Augustine appears to undermine his own anthropological explanation of evil when to counter the Pelagian excesses concedes that $\sin$ is a hereditary taint biologically transmitted ${ }^{9}$ For Duffy (1988, 607 ), the apparent contradiction between responsibility and inevitability appears largely due to Augustine's mixture of categories: a juridical category of debt, which concerns deliberate and therefore punishable acts, and a biological category of inheritance, which concerns species unity through propagation. Augustine directed the juridical category against the Manicheans, as he insisted on the separation of the beginning of creation from the beginning of evil, and the biological category against the Pelagians, as he insisted on a pre-volitional solidarity in evil grounded in procreation, which, of course, awakened the ancient associations, dormant in archaic layers of consciousness, between stain and sexuality. Thus the doctrine appeared incoherent, though its central insight -that the bondage of the heart to evil is selfimposed and that freedom and inevitability, individuality and solidarity are paradoxically related rather than starkly contradictory- is profound. Eventually, the stock explanation of inherited guilt and corruption resulting from the inclusion of all of us in Adam's loins made the classical doctrine hard to distinguish from its Gnostic rival, for sin came to appear as an intrinsic and inescapable dimension of the human condition for which no one is or can be liable.

That said, the brilliance of Augustine's insight enables us to see that two types of language have to be held in paradoxical tension in speaking of evil as both moral and tragic: that of freedom and that of inevitability, contingency and universality, responsibility and inescapability. This double negation of Manichaeism and Pelagianism would lead Augustine to the classical doctrine of original sin with its three pivotal points: original perfection, original sin, and original guilt. However, his battle against Pelagianism pushed Augustine to the bitter end in developing the notion of original sin. If creation and fall are not temporally separated as before and after, how distinguish the origin of creation from the origin of evil or sin from finitude? How sever the link between a historical fall and the corruption of human nature without surrendering to a Pelagian naiveté that sees humanity as always the same and poised indifferently before good and evil? Conversely, how concede evil's irreducibility without going over to Manichaeism? Augustine never ceased to struggle with the implications of this paradox. As it is beautifully put by Neil Forsyth (1987, 408), 'until he could understand the structure of his life and its relationship to the structure of sin and grace, of light and darkness, that operates everywhere and at once, he was always in danger either of Pelagian optimism or Manichean pessimism'.

It is no coincidence then that in the history of ideas Augustine was accused of failing to overcome both Gnosticism and Pelagianism. For Hans Jonas, Augustine fell to the Pelagian argument in his failure to preserve a purified realm of grace, separated absolutely from the state of law; it was a failed attempt at dualism, misguided from the outset (Lazier 2003, 630). For Hans Blumenberg (1985, 135-6), Augustine failed to overcome Gnosticism because he displaced the Gnostic dualism of worldly and transcendent into the dualism of damned and saved, the 'absolute separation of the

\footnotetext{
${ }^{9}$ See here Julian's of Eclanum objection that Augustine is confusing a matter of morals (the will's determination of good and evil deeds) with an issue of biology (the creation of sperm): 'Qui fieri potest ut res arbitrii conditioni seminum misceatur?’ (Augustine, Augustine, 1865, 837)
} 
elect from the rejected.' What both Jonas and Blumenberg failed to register was that while Augustine did propagate a form of ethical dualism that haunted political theology ever since in the form of the 'Doctrine of the Two' (Kirwan 2008, 55), his avowed solution to the problem of evil and human sinfulness explicitly rejected Gnostic ontological dualism. However, Jonas' and Blumenberg's reactions reveal how fragile holding an ethical as opposed to ontological differentiation between an earthly and a heavenly city would prove to be. The twin 'Gnostic' temptations of either purist retreat from a denigrated world or an eschatological outbreak of political messianism ceaselessly loom in the background.

\section{Morgenthau, Schmitt and the 'Gnostic' temptation}

It is exactly this grappling with the ambivalence of holding an ontological monist doctrine while advocating ethical dualism that one discerns in the writings of realist thinkers who have struggled with the paradox of the human condition such as Hans Morgenthau and Reinhold Niebuhr. Early realist thought, as it is expressed in the work of those thinkers, seems to be soberly conscious of the pathological structure of existence (man's propensity to evil) while eschewing any facile slide to cynicism and meaninglessness. At the same time, however, Niebuhr and Morgenthau are not equally susceptible to the 'Gnostic' temptation. Morgenthau seems to be closer to a 'Gnostic'-like dichotomous sensibility that may perhaps be traced back to a peculiar mix of Nietzschean scepticism and Kantian transcendentalism in his thought. ${ }^{10}$ Niebuhr, on the other hand, remains faithful to the Augustinian tradition with a twist that seeks to dissociate it from traces of 'Gnostic' or neo-orthodox otherworldliness.

Morgenthau's ambivalent mood is most characteristically depicted in his reading of the tragedy of human condition that is inextricably linked to his Nietzschean (Neacsu 2010; Frei, 2001) and Weberian-like (Pichler 1998) diagnosis of the 'death of God' and disenchantment in late modern, post-metaphysical societies. The capacity to rationally discover an ultimate foundation upon which to construct an unshakable meaning of the world is no longer available and men must learn to meet under an empty sky from which the gods have departed' (Morgenthau 1967, 249). However, simultaneously Morgenthau does not fail to notice that humanity's irretrievably lost ability to ascribe a stable meaning to the world does not necessarily lead to a despairing nihilism. In a typically Nietzschean manner (Nietzsche 2006, 67), he believes that the indeterminacy and uncertainty ensuing the irrecoverable loss of humanity's innocence and security after the collapse of religious and metaphysical certainties may be seen as a liberating development allowing human beings to re-activate their dormant potentialities ('vitalities' as he calls them) (Neacsu 2010, 53; Williams 2004, 649; Tjalve 2008).

Morgenthau is inspired by a near-Heideggerian (Spegele 2009) philosophical sensibility that refuses to reduce the rich and complex texture of experience to the cognitive demands of humanity's epistemic will to power. In Scientific Man vs. Power Politics, Morgenthau (1946) attacks rationalism exactly because in its certainty for the attainability of fulfilment and perfection it violates the meaningfulness of life in its entirety by compressing the whole of human experience into a system. Morgenthau recognises in this the tragedy of the human condition. Humans are driven by the will to ascribe meaning to their social existence but social reality

\footnotetext{
${ }^{10}$ See, here, Frei (2001), Petersen (1999) and Paipais (2014).
} 
cannot answer the riddles of existence as it stands as a constant reminder of human being's impotence to embrace the totality of experience. Meaningful action is always gained at the expense of our infinite desire. In Morgenthau's $(1946,221)$ language, the statesman -who is the prototype of social man-, is forever stranded between 'what he needs and wants and what he is able to obtain':

Suspended between his spiritual destiny which he cannot fulfil and his animal nature in which he cannot remain, he is forever condemned to experience the contrast between the longings of his mind and his actual condition as his personal, eminently human tragedy.

Despite its heroic tone or, rather, because of it, the problem with this understanding of the relationship between human desire (freedom) and necessity is that it postulates an unbridgeable gap between transcendence and immanence. This is more than evident in Morgenthau's wholesale embracement of the Pascalian sensibility that views human beings as always oscillating between the inexorable determinism of nature and their ability to transcend finitude (Morgenthau 1946, 223). His target here is rationalist monism and its tendency to reduce human agency to the determinism of discoverable laws. Yet, he runs the risk of erecting an unbridgeable chasm between a fallen reality and the human ability to transcend it which comes perilously close to the Augustinian wrestling with the 'Gnostic' temptation of an original dualism constituting the perennial forces that govern the world: 'The prerationalist age is aware of the existence of two forces -God and the devil, life and death, light and darkness, good and evil, reason and passion- which struggle for dominance of the world (Morgenthau 1946, 205)'.

Morgenthau's ambivalence on this matter may provide an explanation for some of the caricaturing or mislabelling of his political ethics. Critics such as Michael Smith (1986, 135-137) and Michael Loriaux (1992: 416) have argue that the centrality of animus dominandi and the ubiquity of evil in Morgenthau's thought evacuates effective individual moral responsibility (see also Klusmeyer 2009). This is admittedly a misleading remark if one takes into account that most of Morgenthau's work is geared towards the salvation of human agency and the exercise of political wisdom as a form of ethical action amidst the contingent temporal and spatial circumstances that make up political life (Molloy 2009; Murray 1996). Morgenthau is at pains to stress that there is only one universal moral code applied across individuals and collectivities and that no political expediency justifies the application of double moral standards. However, there is some truth to the criticism that Morgenthau never managed to justify satisfactorily the nature of his political ethics. This is, I argue, a result of his failure to sustain the difference between an ontological and an ethical dualism in his ethico-political discourse. Although it would indeed be wrong to call Morgenthau a full-fledged 'Gnostic', Roger Epp $(1991,25)$ is right to attribute Morgenthau's ambiguity to his lack of theological skills. ${ }^{11}$ For Epp, Morgenthau's ersatz concept for sin expressed in secular terms as an insatiable lust for power shapes the human condition prior to any meaningful realm of freedom.

\footnotetext{
${ }^{11}$ This is a remarkable claim not only because it proves the Schmittian point about the relevance of theological notions in politics but also because it reveals the crucial role of theology as such in providing the symbolisms and an effective, time-honoured vocabulary to think through the dilemmas of politics and the structure of experience (see Ricoeur 1967).
} 
It is here that Morgenthau's emphasis on the 'ubiquity of evil' in political life may rightfully sound disarmingly pessimistic (Morgenthau 1945) or overly romantic (Morgenthau 1962). That political action is bound to fail or that it necessarily, $a b$ initio, carries the mark of its own corruption is one thing but the attribution of that failure to an ontological necessity of evil is quite another. The former may still allow for a residual human responsibility and capacity for justice despite or even through the tragic conditions that beset human existence (ethical dualism); the latter locates tragedy in the irreconcilable dichotomy between an a priori fallenness of actual life and a transcendental realm of ethical norms that are recognised but dismissed as not directly applicable to actual life (ontological dualism). In the absence of any creative dialectical overcoming of this opposition ethical dualism may easily regress to an ontological one. The claim here is not that Morgenthau does not have a concept of moral responsibility or that he programmatically opts for nihilism. On the contrary, he laments and fights this tendency in modernity (Frei 2001, 141-3). The criticism is that because he does not explicitly differentiate between human freedom and finitude his ethical dualism runs the danger of imperceptibly sliding into an ontological one. As a result anthropological pessimism or heroic fatalism is more likely to cripple his political ethics (see Morgenthau 1961, 234; compare with Rice 2008, 285-9 and Levine 2012, 120-135). As Roger Epp (1991:19) rightfully remarks, '[a] great gulf separates this attitude from Niebuhr's contention that despair was the fate of those realists who knew something about sin, but nothing about redemption'.

Despite Morgenthau's ambivalence, however, it would be misleading to equate the premises of his political theology with Schmitt's more explicit indebtedness to 'Gnostic' thought patterns and their anthropological implications. Schmitt (2006) believes that there are two kinds of political theories: those ones that presuppose a conception of human nature as evil and take original sin seriously; and those ones that either gloss over this fact or deny it altogether imagining human nature as inherently good or positively malleable. Schmitt admits to a 'pessimistic anthropology' and claims 'all genuine political theories presuppose man to be evil.' (cf. Meier 1998, 80) In fact, expressed theologically, Schmitt's anthropology is marked by original sin. Heinrich Meier $(1995,57)$ goes as far as to claim, 'Original sin is the central point around which everything turns in [Schmitt's] anthropological confession of faith.' To be sure, to the old unresolved problem of the world's imperfection in need of redemption, Schmitt may side with those theodicies that take original sin seriously; yet, his understanding of it sounds more 'Gnostic' than orthodox Christian. Schmitt's political realism grounded on the friend/enemy distinction can be read as the secularisation of this theological concept but with a spin that sheds light on his 'Gnostic' interpretation of man's evil nature.

Indeed, Schmitt's unrelenting insistence on the evil of man in metaphysical rather than moral terms and on the loneliness and depravity of the world, in general, seem to validate his proximity to 'Gnostic' modes of thought (see Hohendal 2008). ${ }^{12}$ In

\footnotetext{
12 For a further substantiation of Schmitt's 'Gnostic' tendencies, see here the excellent article by Hohendal (2008) and studies by Groh (1998) and Manemann (2002). Schmitt himself was convinced that the implantation of the concept of enmity at the heart of the political could, in a sense, recalibrate the Catholic dogma towards what he termed the 'intensification of Catholicism' (katholische Verschärfung) (Wacker, 1994) which he understood as a form of radicalisation of the Catholic doctrine in line with his avowed decisionism. Excellent sources for Schmitt's religious leanings and theological reflections are the two volumes of notes and ruminations from the years immediately after World War II, the Glossarium and Ex Captivitate Salus. For a Catholic response to the Manichean tendencies in Schmitt's thought, see Gustav Gundlach's critique in Lönne (1994). For an argument that
} 
fact, Schmitt's political theology cannot be sustained if the grounds of enmity -the metaphysics of the political- are not eventually located within the deity itself. Schmitt (2008) becomes aware of what his political theology necessitates in his response to Erik Peterson (2011), a theologian who questioned the meaningfulness of political theology on the grounds that the concept of the Divine Trinity runs against any recruitment of the idea of monotheism to legitimise either monarchical government or political authoritarianism. Schmitt replies to Peterson's objection by transplanting enmity within the Christian Trinity: the unity of God includes the hostility between God the Father and God the Son (Hohendal, 2008: 16; Groh, 1998: 160)..$^{13}$ This is far from a Catholic doctrine. If one divides the two persons of God into Christ the rebel who must turn against his Father, the work of redemption is dangerously subordinated to the priority of the political as expressed in Christ's promethean defiance (Groh, 1998: 163). This assumption throws light on the specific character of Schmitt's katechontic political theology: its political perspective is not Christ the redeemer but the opposition of imperfect creation (secular history, the state) and redemption (eschatology as perpetually deferred) which, however, sounds alarmingly 'Gnostic'.

In contrast to Schmitt's anthropology, Morgenthau does not subscribe to the Schmittian understanding of human nature as inherently evil. Thus, the 'Gnostic' temptation in Morgenthau does not arise from the endorsement of some programmatic human predilection towards conflictuality; rather, like in Augustine, human propensity to evil emerges as an outcome of frustrated love (Morgenthau 1962). Yet, the gap that opens between a world surrendered to the will to power and the possibility of redemption in love is inexorable: 'whatever he expects of the other world, [man] must leave this world as he entered it: alone' (Morgenthau 1962, 251). The lack of a clear articulation of a theory of freedom of the will prior (not chronologically but ontologically) to man's surrender to evil makes Morgenthau vulnerable to the 'Gnostic' temptation (expressed as secular Nietzcheanism in his thought, see Frei 2001) of a permanent disjuncture between a world destined to damnation and an impossible redemption.

\section{Overcoming ‘Gnosticism’ 2.0? Niebuhr’s realist political theology}

If Schmitt's political theology exemplifies the strong allure of 'Gnostic' ontological dualism and Morgenthau's inconsistencies in holding an ethically dualist doctrine while flirting with the 'Gnostic' temptation of a dualistic ontology, Niebuhr's theological anthropology foregrounds realism's ontologically monist credentials. To that extent, Niebuhr's realist political theology emerges as a clear indictment of 'Gnosticism's' politics of purism and a creative reworking of Augustinian ethical dualism. In fact, Niebuhr's realist pragmatism can be properly appreciated only if it is read through its theological presuppositions.

\footnotetext{
Schmitt's Catholicism represented a special breed of German nationalistic Catholicism based on race rather than church universal, see Geréby (2008).

${ }^{13}$ Relying on an idiosyncratic interpretation of an aphorism by Gregory of Nazianzus, Schmitt (2008: 123) asserts that ' $[\mathrm{a}] \mathrm{t}$ the heart of the doctrine of the Trinity we encounter a genuine politicaltheological stasiology. Thus the problem of enmity and of the enemy cannot be ignored'. The ambivalence of the word stasis in Greek, meaning both tranquillity and political upheaval, allows Schmitt to establish Gnostic dualism as an almost inescapable existential predicament between forces who are enemies 'by definition' (both emphases in original) (2008: 125).
} 
The key to unpacking Niebuhr's anti-'Gnostic' political theology lays in his modified Augustinian outlook on original sin. Niebuhr's ethical realism rests on the Augustinian interpretation of original $\sin$ as a lapsus of the human will. As mentioned earlier, for Augustine, sin is not a natural human handicap grounded in elemental human biology but a failure of the will due to man's love for himself (cupiditas). Like Augustine, Niebuhr does recognise that the Christian concept of original sin belies an absurdity in the form of refusing to accept sin as a permanent taint on human nature, at the same time that it considers evil tendencies in human beings almost inevitable. Original sin then appears paradoxically to affirm both man's 'inherited corruption' and individual responsibility. However, whereas, as we have seen, this ambiguity have proved almost unbearable to Augustine himself leading him to adopt a hereditary 'Gnostic'-like grounding of human sinfulness, Niebuhr opted for a more dynamic understanding of the paradoxical human condition inspired by Kierkegaard's existentialism (Niebuhr 1954; Patterson 1999, 50). To escape ending up in the same bind as Augustine, he adopts Kierkegaard's view that $\sin$ is neither a necessity nor an accident but a temptation that is intimately connected with the relation of sin to anxiety (Kierkegaard 1980). In that, he goes beyond his mentor Augustine's belief in the fundamental depravity that taints humanity by birth moving perhaps closer to a semi-Pelagian position.

Indeed, Niebuhr's anthropology relies on the orthodox Christian doctrine of man as imago Dei, that is, as a creature that besides his animal nature shares with God certain transcendent qualities that enable him to overcome the limitations of his created nature. Although he does not share the ability to create out of nothing (creatio ex nihilo) he is nevertheless endowed by God with creative capacities and the ability to make moral choices. Because of this unique gift of freedom man is, for Niebuhr, a peculiar creature that always operates at the juncture of time and eternity sharing a bit of both. Niebuhr calls this duality of being simultaneously inside and outside nature 'a vertical dialectic' (Gilkey 2002, 16), meaning that man is at once physical and supernatural. This is not the Manichean dualism of a debased natural existence, on the one hand, and an exalted spiritual one, on the other. On the contrary, man for Niebuhr is a unified personality 'caught in the tension of limited self and unlimited potential' (Patterson 1999, 49). It is within this understanding of the paradoxical tension between finitude and freedom marking human existence that Niebuhr's insistence on the sinfulness of all men should be read. Men are not condemned to sin because they are naturally deprived of the ability to do good; rather, because they willfully choose to do evil. The choice of evil is not a defect of nature but a perversion of his creative capacity into pride which according to Augustine is man's forgetfulness of his dependence on God. Freedom leads to sin because man seeks security by his own efforts. This view is best summarised by Niebuhr's (1943, 80) Augustinian remark: 'where there is history at all there is freedom, where there is freedom there is sin'.

However, the fact that sin is a fundamental part of the human condition does not mean that evil resides 'in some sloth of nature which man has inherited from his relation to the brute creation' (Niebuhr 1941, 246). On the contrary, Niebuhr (1964, 38 ) believes that men are 'egoists in contradiction to their essential natures'. It is sin not finitude that begets evil and sin is to deny the anxiety that comes from man's finitude (the fact that man is a created being). That is why it is not attending to the reality of human limitations that reduces evil, for Niebuhr, but adopting the correct attitude towards those limitations (repentance is never separated from hope). In that sense, properly understood, Niebuhr's 'Christian realist claim that there are no limits 
to our moral achievements within history is not an invitation to pride but to politics' (Lovin 1995, 157). My claim is that Niebuhr can credibly support this case because his theology is one of eschatological hope. It comprehends the tragedy of the human condition not as the effect of an inexorable fate or the unbridgeable gap between our transcendent ideals and a less than perfect and complex reality (ontological dualism) but as a result of the contradictory relationship between human freedom and its demonic tendencies (ethical dualism).

Niebuhr has too often been branded a pessimist. His popular image was that of a realist Protestant theologian that never failed to remind us: 'Man's story is not a success story'. ${ }^{14}$ Indeed, Niebuhr's theology was strongly influenced by the negativity of Christ's sacrifice on the cross as an image of judgment upon all human success stories. However, it would be a crudity to label Niebuhr a pessimist, not least because designations such as 'optimist' or 'pessimist' would not faithfully depict his complex but ultimately orthodox Christian theology. As Douglas Hall (1998, 51) observes this assessment...is the judgment of little minds for whom the facile alternatives of optimism and pessimism are substitute for more mature categories of analysis'. What is mistakenly taken to be an expression of pessimism or even fatalism is Niebuhr's anti-purist spirit that refuses to accept the liberal-Renaissance naivete of the constant virtuousness of humanity at the same time, however, that he negated the view of history and earthly politics as ubiquitously evil. Critics are often mislead by the stark opposition between the individual ethics of perfection and the violent ethics of coercion that one finds in Niebuhr's early work, Moral Man and Immoral Society. Indeed, in this book Niebuhr approximates the neo-orthodox spirit of the otherworldliness of religious commitments as a reaction to Social Gospel's misplaced optimism. However, ever since the publication of Reflections on the End of an Era, Niebuhr moved away from what resembled the near irrelevance of the Christian ethic of love for public life towards a more dialectical attitude that recognises the operation of the ideal in the real (Erwin 2013; Naveh, 2002). ${ }^{15}$ It is often forgotten by all those who describe his theology as unquestionably neoorthodox that volume II of his The Nature and Destiny of Man calls for a synthesis of Reformation and the Renaissance conceptions of man and history (see Shinn 1974, 411). For Niebuhr (1943, 207), despite the fact that we all operate in sin and that competition is never between the sinners and the righteous but between sinful men of varying degrees, we must learn from the Renaissance that 'life in history is filled with indeterminate possibilities' and that men in history are faced with the responsibility to realise them even while with Reformation we know that only grace can be the answer to the corruptibility of human achievements.

The foundation of Niebuhr's pragmatic spirit is actually this dialectical tension between contrition and hope, Reformation and Renaissance. His pragmatism then has to be read not as disarming scepticism or middle-way accommodationism; rather it should be approached through its theological underpinnings as fidelity to

\footnotetext{
14. That was the caption under the portrait of Reinhold Niebuhr set against the backdrop of a turbulent stormy landscape with a cross on the horizon that appeared on the cover of Time magazine's 25 ht anniversary issue. It reveals a great deal about the ambiguous power of images to vividly illustrate a point at the same time they distort it.

${ }^{15}$ Naveh calls this attitude 'non-utopian liberalism' while Erwin describes Niebuhr's effort to combine prophetic judgement with eschatological hope as 'in the battle and above it' alluding to the Pauline injunction that Christians should be in the world but not of this world. For good analysis on what Halliwell (2005) describes as Niebuhr's 'untidy dialectic' between poet, prophet and statesman, see articles by Mac McCorkle, Ian Markham and Robin Lovin in Harries \& Platten (2010).
} 
Augustine's dialectical paradox of the original sin: a constant oscillation and tension between an essentialising 'Gnosticism', on the one hand, that denies individual responsibility for evil and Pelagian optimism, on the other, that thinks of moral action as unencumbered by the circumstances within which it is born and which conditions it. On this point, Niebuhr's eschatology differs markedly from the Barthian variant of neo-orthodoxy as well. Niebuhr is cautiously keeping a distance from Barthian otherworldliness while affirming a positive resolution of the human paradox of freedom that comes closer to Paul Tillich's affirmation of the historical world. As for Tillich, although the Unconditioned cannot be bound by any period of time, yet it can be possible because a kernel of it is always already there, so for Niebuhr $(1943,291)$ although worldly powers are always transitory and the object of God's sovereign judgement, history is filled with endless possibilities for the realisation of human creative potentials:

Against utopianism the Christian faith insists that the final consummation of history lies beyond the conditions of the temporal process. Against other-worldliness it asserts that the consummation fulfils rather than negates the historical process.

\section{Conclusion}

In this paper, I have demonstrated how interpreting realist political theology as a Schmittian or strictly neo-orthodox project narrates half of the story. Undoubtedly, Schmitt exercised a strong influence on realist conceptualisations of political power as restraining force preventing social chaos. Yet, describing the realist project as an extension of Schmittian political theology is associating realism too closely with 'Gnostic' tendencies in the neo-orthodox movement with which Schmitt's project of 'intensification of Catholicism' seemed to coincide but which contained only part of the tensions that Augustinian political realism grappled with. In fact, the radical break between transcendence and immanence that both Schmitt and Barthian neoorthodoxy announce in their work does not sit easily with the dialectical paradox of sin and responsibility in Augustine's thought which prominent realists such as Morgenthau and Niebuhr shared and sustained in a greater or lesser degree.

That said, realism's struggle with 'Gnosticism' is not a story of victory or defeat but a tale of constant wrestling against the 'Gnostic' temptation. To the extent that Morgenthau's and Niebuhr's thought is a peculiar mixture of Schmittian, neoorthodox and Augustinian elements their thought also exhibits the ambiguity and uneasy compromise between 'Gnostic' dualism and more dialectical forms of orthodox Christianity. The picture here is a lot more complicated than simply representing realists as defenders of some form of Christian orthodoxy. Gershom Scholem once astutely observed that 'Gnosticism' is not simply a heretical deviation from the orthodox dogma but 'a constantly self-repeating structure within religious thinking' (cf. Wiese 2007, 65). The 'Gnostic' impulse in religious thought emanates from the human being's struggle to balance two contradictory injunctions: the coexistence of evil with an omnipotent and benevolent God. By studying realism, then, as anti-'Gnostic' tragic theology, we gain a better understanding of the theological background to the realist tragic vision of politics. This vision, if understood as an attempt by Augustinian realists to grapple with the problem of evil and position themselves vis à vis the Augustinian paradox of the original sin, may in turn explain the kind of pragmatism realism advocated. Not an untroubled pragmatism of the Deweyan persuasion, but a theological pragmatism steeped in the doctrines of sin and tragedy; concerned not with offering compromises but rather with keeping the 
paradox of human existence free from enslavement to idolatrous totalitarianisms of any spiritual or political kind.

Reading realist ethics as a struggle against 'Gnostic' tendencies may also help explain the reasons behind the frequent misinterpretation or abuse of realist thought. As it became apparent from the allusions to the powerful drive towards 'Gnostic' dualism, the dialectical element or rather the creative tension that realists advocated between the imperatives of power and morality is hard to sustain. Inevitably, critics tended to see them as either hard-nosed power politics figures as well as apologists of violence and imperialism legitimising the Cold War politics of the American superpower or as non-gratifying moralists advancing a moral skepticism that leads to unbelief and inaction. However, politics for the realists is an exercise of power but not in moral vacuum. Moral action is condemned to take place in an always already structured (corrupted) environment but not because the created world is inherently evil or history the site of man's inevitable debasement. Rather, because humans enter a world already structured by sin as a dark involuntary in the heart of human will and marked by habitual cowardice and impotence to counteract it. Dissociating human finitude from sin enables eschatological hope to shine even in the middle of a despairing reality as the promise of the ideal in the actual. Yet, to offset a naïve idealism that interprets history as moving towards the progressive approximation of an ideal reality, realists take the self-contradicting power of freedom and the demonic tendencies in history seriously. Eschatological hope presupposes repentance and contrition if it is to inspire progressive activism as opposed to otherworldly quietism or hollow utopianism and political messianism. Realist political theology teaches us how important it is to nurture the dialectic of humility and hope.

\section{REFERENCES}

Augustine, Saint (1998) Confessions (London; New York: Penguin Books).

Augustine, Contra Julianum, PL 44: 641-874.

Barth, Karl (1968[1933]) Epistle to the Romans (Oxford: Oxford University Press).

Barth, Karl (1960) The Humanity of God (Louisville: John Knox Press).

Blumenberg, Hans $(1985[1966])$ The Legitimacy of the Modern Age trans. Robert H. Wallace (Baskerville: MIT Press).

Cremer, Douglas J (1995) 'Protestant Theology in Early Weimar Germany: Barth, Tillich, and Bultmann', Journal of the History of Ideas, 56:2, 289-307.

Critchley, Simon (2012) The Faith of the Faithless: Experiments in Political Theology (London; New York, Verso).

Dods, Marcus (1950), trans. Augustine: The City of God, (New York: Modern Library).

Duffy, Stephen J (1988) 'Our Heart of Darkness: Original Sin Revisited', Theological Studies, 49, 597-622. 
Epp, Roger (2003) 'The Ironies of Christian Realism: The End of the Augustinian Tradition in International Politics' in Eric Patterson (ed.) The Christian Realists: Reassessing the Contributions of Niebuhr and his Contemporaries (Lanham, MD: University Press of America), 199-232.

Epp, Roger (1991) 'The 'Augustinian Moment' in International Relations: Niebuhr, Butterflied, Wight and the Reclaiming of a Tradition', Aberystwyth, UK: Department of International Politics, University College of Wales, International Politics Research Paper no. 10.

Erwin, Scott (2013) The Theological Vision of Reinhold Niebuhr's The Irony of American History: 'in the battle and above it', (Oxford: Oxford University Press).

Forsyth, Neil (1987) The Old Enemy: Satan and the Combat Myth (New Jersey: Princeton University Press).

Frei, Christopher (2001) Hans J. Morgenthau: An Intellectual Biography (Baton Rouge: Louisiana State University Press).

Geréby, György (2008) 'Political Theology versus Theological Politics: Erik Peterson and Carl Schmitt', New German Critique, 35:3 105, 7-33.

Gilkey, Langdon (2001) On Niebuhr: A Theological Study (Chicago: Chicago University Press).

Groh, Ruth (1998) Arbeit an der Heillosigkeit der Welt. Zur politisch-theologischen Mythologie Carl Schmitts (Frankfurt/Main: Suhrkamp).

Guilhot, Nicholas (2010) 'American Katechon: When Political Theology Became International Relations Theory', Constellations, 17:2, 224-253.

Hall, Douglas J (1998) Remembered Voice: Reclaiming the Legacy of 'Neo-Orthodoxy' (Louisville: John Knox Press).

Hall, Ian (2006) The International Thought of Martin Wight (New York: Palgrave Macmillan).

Halliwell, Martin (2005) The Constant Dialogue: Reinhold Niebuhr and American Intellectual Experience, (Lamham, Md: Rowman \& Littlefield).

Harries, Richard and Platten Stephen (eds.) (2010) Reinhold Niebuhr and Contemporary Politics: God and Power, (Oxford: Oxford University Press).

Hermens, Ferdinand A (1958), 'Ethics, Politics, and Power: Christian Realism and Manichaean Dualism', Ethics, 68:4, 246-259.

Hohendahl, Peter U (2008) 'Political Theology Revisited: Carl Schmitt's Post-war Reassessment', Konturen, 1, 1-28. 
Hotam, Yotam (2007) 'Gnosis and Modernity: a Post-war German Intellectual Debate on Secularisation, Religion and 'Overcoming' the Past', Totalitarian Movements and Political Religions, 8:3-4, 591-608.

Jonas, Hans (1992) The Gnostic Religion: the message of the alien God and the beginnings of Christianity (London: Routledge).

Jones, Charles A (2003) 'Christian Realism and the Foundations of the English School', International Relations, 17:3, 371-387.

Kierkegaard, Søren (1980) The Concept of Anxiety: a simple psychologically orienting deliberation on the dogmatic issue of hereditary sin trans. R. Thomte (New Jersey: Princeton University Press).

King, Karen L (2003) What is Gnosticism? (Cambridge, MA \& London: The Belknap Press of Harvard University Press).

Kirwan, Michael (2008) Political Theology: An Introduction (Minneapolis: Augsburg Fortress).

Klusmeyer, Douglas (2009) 'Beyond Tragedy: Hannah Arendt and Hans Morgenthau on Responsibility, Evil and Political Ethics', International Studies Review, 11:2, 332-351.

Lazier, Benjamin (2008) God Interrupted: Heresy and the European Imagination between the World $W$ ars (New Jersey: Princeton University Press).

Lazier, Benjamin (2003) 'Overcoming Gnosticism: Hans Jonas, Hans Blumenberg and the Natural World', Journal of the History of Ideas, 64:4, 619-637.

Levine, Daniel J (2012) Recovering International Relations: The Promise of Sustainable Critique (Oxford: Oxford University Press).

Lilla, Mark (2007) The Stillborn God: Religion, Politics and the Modern West (New York: Vintage Books).

Lönne, Karl-Egon (1994) 'Carl Schmitt und der Katholizismus der Weimarer Republik' in B. Wacker ed., Die eigentlich katholische Verschärfung: Konfession, Theologie und Politik im Werk Carl Schmitts (München: Fink).

Loriaux, Michael (1992) 'The Realists and Saint Augustine: Skepticism, Psychology, and Moral Action in International Relations Thought', International Studies Quarterly $36: 4,401-420$.

Lovin, Robin W (1995) Reinhold Niebuhr and Christian Realism (Cambridge: Cambridge University Press).

Löwith, Karl (1949) Meaning in History (Chicago: University of Chicago Press).

Manemann, Jürgen (2002) Carl Schmitt und die Politische Theologie. Politischer AntiMonotheismus (Münster: Aschendorff). 
Meier, Heinrich (1998) The Lesson of Carl Schmitt: four chapters on the distinction between political theology and political philosophy trans. Marcus Brainard (Chicago: University of Chicago Press).

Meier, Heinrich (1995) Carl Schmitt and Leo Strauss: the hidden dialogue trans. J. Harvey Lomax (Chicago: University of Chicago Press).

Metz, Johann Baptist (1988) 'Theologie gegen Mythologie. Kleine Apologie des biblischen Monotheismus', Herder Korrespondenz, 4, 187-193.

Morgenthau, Hans J (1967) Politics Among Nations: The Struggle for Power and Peace 4th edition (New York: Alfred A. Knopf).

Morgenthau, Hans J (1962) 'Love and Power', Commentary, 33, 247-251.

Morgenthau, Hans J (1961) 'Death in the Nuclear Age,' Commentary, 32, 231-234.

Morgenthau, Hans J (1946) Scientific Man vs. Power Politics (Chicago: University of Chicago Press).

Morgenthau, Hans J (1945) 'The Evil of Politics and the Ethics of Evil', Ethics, 56:1, $1-18$.

Molloy, Sean (2009) 'Hans J. Morgenthau Versus E. H Carr: Conflicting Conceptions of Ethics in Realism' in D. Bell ed., Political Thought and International Relations: variations on a realist theme (Oxford; New York: Oxford University Press), 83-104.

Murray, Alasdair H J (1996) 'The Moral Politics of Hans Morgenthau', The Review of Politics, 58:1, 81-107.

Naveh, Eyal (2002) Reinhold Niebuhr and Non-Utopian Liberalism: Beyond illusion and despair (Brighton; Portland: Sussex Academic Press).

Neacsu, Michaela (2010) Hans J. Morgenthau's Theory of International Politics: Disenchantment and Re-Enchantment (Basingstoke: Palgrave Macmillan).

Niebuhr, Reinhold (1964) Christianity and Power Politics (New York: Charles Scribner \& Sons).

Niebuhr, Reinhold (1954) Christian Realism and Political Problems (London: Faber and Faber Ltd).

Niebuhr, Reinhold (1943) The Nature and Destiny of Man: a Christian interpretation, Vol. II Human Destiny (London: Nisbet \& Co. Ltd).

Niebuhr, Reinhold (1941) The Nature and Destiny of Man: a Christian interpretation, Vol. I Human Nature (London: Nisbet \& Co. Ltd). 
Nietzsche, Friedrich (2006) Thus Spoke Zarathustra: A Book for All and None (Cambridge: Cambridge University Press).

Pabst, Adrian (2012) 'Realism beyond secular reason: religion and the revival of grand theory in IR', Review of International Studies, 38:5, 995 - 1017.

Paipais, Vassilios (2014), Between Politics and the Political: reading Hans J. Morgenthau's double critique of depoliticisation', Millennium: Journal of International Studies (forthcoming).

Patterson, Eric (1999) 'Niebuhr and His Critics: Realist Optimism in World Politics', International Relations, 14:47, 47-65.

Petersen, Ulrich E (1999) 'Breathing Nietzsche's Air: New Reflections on Morgenthau's Concepts of Power and Human Nature', Alternatives, 24:1, 83-118.

Peterson, Erik (2011), 'Monotheism as a Political Problem: A Contribution to the History of Political Theology in the Roman Empire' in M. Hollerich ed., Theological Tractates, (Stanford: Stanford University Press), 68-105.

Pichler, Hans K (1998) 'The godfather of 'truth': Max Weber and Carl Schmitt in Morgenthau's theory of power politics', Review of International Studies, 24, 185-200.

Rice, Daniel (2008) 'Reinhold Niebuhr and Hans Morgenthau: A Friendship with Contrasting Shades of Realism', Journal of American Studies, 42:2, 285-289.

Ricoeur, Paul (1974) 'Original Sin: A Study in Meaning', in D. Ihde (ed) The Conflict of Interpretations: Essays in Hermeneutics (Evanston: Northwestern University), 269286.

Ricoeur, Paul (1967) The Symbolism of Evil trans. Emerson Buchanan (Boston: Beacon Press).

Rossbach, Stefan (2005) “'Gnosis” in Eric Voegelin's Philosophy', Political Science Reviewer, 34, 77-121.

Rossbach, Stefan (1999) Gnostic Wars: The Cold War in the Context of a History of Western Spirituality (Edinburgh: Edinburgh University Press).

Schmitt, Carl (2008) Political Theology II: The Myth of the Closure of Any Political Theology (Cambridge: Polity Press).

Schmitt, Carl (2006) Political Theology: four chapters on the concept of sovereignty trans. G. Schwab (Chicago: University of Chicago Press).

Shinn, Roger (1974) 'Realism, Radicalism and Eschatology in Reinhold Niebuhr: A Reassessment', The Journal of Religion, 54:4, 409-423.

Smith, Michael (1986) Realist Thought from Weber to Kissinger (Baton Rouge: Louisiana State University Press). 
Spegele, Roger (2009) 'Towards a More Reflective Political Realism' in D. Bell ed., Political Thought and International Relations: variations on a realist theme (Oxford; New York: Oxford University Press), 83-104.

Taubes, Jacob (2004) The Political Theology of Paul trans. Dana Hollander (Stanford, CA: Stanford University Press).

Thomas, Scott (2001) 'Faith, History and Martin Wight: The Role of Religion in the Historical Sociology of the English School of International Relations', International Affairs, 77:4, 905-929.

Tjalve, Vibeke S (2008) Realist Strategies of Republican Peace: Niebuhr, Morgenthau and the politics of patriotic dissent (New York: Palgrave MacMillan).

Troy, Jodok (ed) (2013), Religion and the Realist Tradition: From Political Theology to International Relations Theory and Back, (London: Routledge).

Versluis, Arthur (2010) 'The 'Counterculture', Gnosis and Modernity', Telos, 152, 31-43.

Versluis, Arthur (2006) The New Inquisitions: Heretic-Hunting and the Origins of Modern Totalitarianism (Oxford: Oxford University Press).

Voegelin, Eric (1990), Anamnesis, G. Niemeyer ed. (Columbia and London: University of Missouri Press).

Voegelin, Eric (1952) The New Science of Politics: an introduction (Chicago: the University of Chicago Press).

Wacker, Bernd (ed) (1994) Die eigentlich katholische Verschärfung: Konfession, Theologie und Politik im Werk Carl Schmitts (München: Fink).

Wiese, Christian (2007) The Life and Thought of Hans Jonas: Jewish dimensions (Lebanon, NH: Brandeis University Press).

Williams, Michael A (1996) Rethinking "Gnosticism": An Argument for Dismantling a Dubious Category (Princeton, NJ: Princeton University Press).

Williams, Michael C (2004) 'Why Ideas Matter in International Relations: Hans Morgenthau, Classical Realism, and the Moral Construction of Politics', International Organization, 58:4, 633-665. 